\title{
Improved n-butanol production via co-expression of membrane-targeted tilapia metallothionein and the clostridial metabolic pathway in Escherichia coli
}

\author{
Wei-Chih Chin ${ }^{1}$, Kuo-Hsing Lin'², Chun-Chi Liư ${ }^{3}$, Kenji Tsuge ${ }^{4}$ and Chieh-Chen Huang ${ }^{1 *}$
}

\begin{abstract}
Background: N-Butanol has favorable characteristics for use as either an alternative fuel or platform chemical. Bio-based n-butanol production using microbes is an emerging technology that requires further development. Although bio-industrial microbes such as Escherichia coli have been engineered to produce n-butanol, reactive oxygen species (ROS)-mediated toxicity may limit productivity. Previously, we show that outer-membranetargeted tilapia metallothionein (OmpC-TMT) is more effective as an ROS scavenger than human and mouse metallothioneins to reduce oxidative stress in the host cell.

Results: The host strain (BUT1-DE) containing the clostridial n-butanol pathway displayed a decreased growth rate and limited n-butanol productivity, likely due to ROS accumulation. The clostridial n-butanol pathway was co-engineered with inducible OmpC-TMT in E. coli (BUT3-DE) for simultaneous ROS removal, and its effect on n-butanol productivity was examined. The ROS scavenging ability of cells overexpressing OmpC-TMT was examined and showed an approximately twofold increase in capacity. The modified strain improved n-butanol productivity to $320 \mathrm{mg} / \mathrm{L}$, whereas the control strain produced only $95.1 \mathrm{mg} / \mathrm{L}$. Transcriptomic analysis revealed three major KEGG pathways that were significantly differentially expressed in the BUT3-DE strain compared with their expression in the BUT1-DE strain, including genes involved in oxidative phosphorylation, fructose and mannose metabolism and glycolysis/gluconeogenesis.
\end{abstract}

Conclusions: These results indicate that OmpC-TMT can increase n-butanol production by scavenging ROS. The transcriptomic analysis suggested that n-butanol causes quinone malfunction, resulting in oxidative-phosphorylationrelated nuo operon downregulation, which would diminish the ability to convert $\mathrm{NADH}$ to $\mathrm{NAD}^{+}$and generate proton motive force. However, fructose and mannose metabolism-related genes (fucA, srlE and srlA) were upregulated, and glycolysis/gluconeogenesis-related genes ( $p f k B, p g m$ ) were downregulated, which further assisted in regulating NADH/ $\mathrm{NAD}^{+}$redox and preventing additional ATP depletion. These results indicated that more NADH and ATP were required in the n-butanol synthetic pathway. Our study demonstrates a potential approach to increase the robustness of microorganisms and the production of toxic chemicals through the ability to reduce oxidative stress.

Keywords: Tilapia metallothionein, OmpC, n-butanol, E. coli, Oxidative stress, Transcriptomic analysis

\footnotetext{
* Correspondence: cchuang@dragon.nchu.edu.tw

'Department of Life Sciences, National Chung Hsing University, Taichung,

Taiwan

Full list of author information is available at the end of the article
} 


\section{Background}

n-Butanol has many advantages over ethanol, including a higher energy density due to two extra carbons, and can be used in gasoline engines without modification. $\mathrm{n}$-Butanol is less hygroscopic and volatile than ethanol and has been recently regarded as a more viable transportation biofuel than ethanol [1-3]. n-Butanol is also a versatile platform chemical that can be produced from a variety of biomass sources. In industry, many important chemicals derived from n-butanol are used extensively as solvents or as intermediates in the production of acrylates, n-butyl acetate, esters, and glycol ethers [4].

Several industrial microbes, including Escherichia coli, have been engineered to produce n-butanol. In the initial stage of engineering E. coli for n-butanol production, the whole n-butanol pathway from Clostridium was transferred to $E$. coli, including the thil, hbd, crt, $b c d$, etf $A$, etf $B$, and adhe (or adhel) genes, catalyzing the six-step conversion of two molecules of acetyl-CoA into one molecule of n-butanol. However, when the clostridial n-butanol pathway was first transferred to $E$. coli using plasmids in 2007, the engineered strain produced less than $1 \mathrm{~g} / \mathrm{L}$ n-butanol (vs. a clostridial nbutanol titer of $10-20 \mathrm{~g} / \mathrm{L}$ ) $[5,6]$. The results indicated that engineering efficient n-butanol-producing $E$. coli is not as simple as expressing several clostridial n-butanol pathway genes. Over the following years, the best heterologous n-butanol-producing strains derived from $E$. coli were able to produce 14-15 g/L n-butanol [7, 8], providing industrial advantages compared to clostridial strains [9]. However, the toxicity of n-butanol to both natural producers and engineered hosts increases with accumulation $[10,11]$. This toxicity complicates the economically efficient production of large titers of nbutanol; therefore, high-titer n-butanol (30 g/L) production currently relies on in situ product removal by continuous gas stripping [8].

Furthermore, although $E$. coli can convert sugars into n-butanol at relatively high levels, the cells cannot tolerate $2 \%(\mathrm{v} / \mathrm{v}) \mathrm{n}$-butanol [11] and produce n-butanol at insufficient levels. Considering the relationship between n-butanol tolerance and n-butanol production in Clostridial strains $[12,13]$, the toxicity of n-butanol to $E$. coli can be considered a production bottleneck. In fact, product toxicity is a widespread problem in the production of biorenewables. Therefore, the development of a stress-tolerant host strain for the bio-production of titerdependent toxic chemicals is important.

To understand the effect of n-butanol toxicity on the host, cell-wide studies have been conducted to obtain a global view of the n-butanol stress-response at the transcript, protein, and metabolite levels. Transcriptomic analysis in Clostridium acetobutylicum indicated that the primary response involved the accumulation of transcripts encoding chaperones, proteases, and other heat shock-related proteins [14].

In $E$. coli, several transcriptional analyses have been performed to investigate the stress caused by alcohols, including ethanol, n-butanol, and isobutanol [15-17]. Additionally, observations from fluorescent dye-staining indicated a large increase in reactive oxygen species (ROS) during n-butanol stress [17]. Increased oxidative stress is a common cellular response to extracellular xenobiotics, which may mediate macromolecular damage. These free radicals can directly attack the membrane via lipid peroxidation or cause DNA mutations, protein misfolding and fragmentation, and apoptosis [18-20].

To decrease ROS-induced oxidative damage, microorganisms synthesize many antioxidant enzymes, including catalases, superoxide dismutases and glutathione peroxidase $[21,22]$. Recently, metallothioneins (MTs), beneficial antioxidant enzymes that occur widely in mammals, plants and fungi, have been identified [23]. MTs are heat-stable, low-molecular-weight and cysteine-rich intracellular proteins [23-25]. MTs also act as a defense system against oxidative stress through their ROS scavenging ability [26]. Furthermore, purified tilapia MT (TMT) has been shown to outperform glutathione (GSH) in scavenging both 2diphenyl-1-picrylhydrazyl $\left(\mathrm{DPPH}^{\bullet}\right)$ and 2,2-azinobis (3-ethylbenzothiazoline- 6-sulfonic acid) diammonium salt $\left(\mathrm{ABTS}^{\bullet+}\right)$ [27]. To reduce oxidative stress in the host cell, we previously engineered MTs into E. coli hosts for both cytosolic and outer-membrane-targeted (osmoregulatory membrane protein, OmpC, fused) expression. The ability of these engineered E. coli to scavenge intracellular or extracellular ROS was examined, and OmpC-fused TMT performed the best, growing in medium containing $1.5 \% \mathrm{n}$-butanol. $\mathrm{n}$ - $\mathrm{Bu}$ tanol tolerance was increased through the scavenging of intracellular and extracellular free radicals, and the fusion protein still contributed to osmotic tolerance via either glycine betaine or glucose uptake [28].

Intracellular ROS increase levels in $E$. coli after exposure to n-butanol [17]. We therefore considered whether introducing OmpC-fused TMT into butanologenic $E$. coli would improve n-butanol tolerance and productivity. In the present study, we engineered the C. acetobutylicum n-butanol synthetic pathway into $E$. coli, along with OmpC-TMT co-expression to increase n-butanol tolerance. A synthetic biological technical platform (Ordered Gene Assembly in Bacillus subtilis - OGAB method) was employed for the genetic manipulation of the n-butanol production and tolerance gene clusters [29]. Our results demonstrate that co-expressing OmpCfused TMT in a butanologenic E. coli strain enhances n-butanol production. 


\section{Results and discussion}

\section{Construction of butanologenic $E$. coli strains}

To establish butanologenic E. coli strains, we transferred only an essential set of genes (thil, crt, bcd, etfAB, hbd, adhe) for n-butanol production [5, 6]. In addition, our previous results indicated that the expression of the ompC-tmt gene enhances the tolerance for $\mathrm{n}$-butanol through osmotic tolerance and extracellular radical scavenging capacity [28]. These genes were cloned and constructed in the plasmid pGETS118 using the OGAB method [29]. The plasmids pBUT, containing Pr-thil-crt-bcd-etfAB-hbd-adhe, pBUT-rO-tMT, containing Pr-thil-crt-bcd-etfAB-hbd-adhe-rbs-ompC-tmt, and pBUT-T7-rO-tMT, with Pr-thil-crt-bcd-etfAB-hbdadhe-T7 promoter-rbs-ompC-tmt, were constructed. The constructed plasmids pBUT, pBUT-rO-tMT and pBUT-T7-rO-tMT (Fig. 1) were used to transform $E$. coli JM109 and E. coli JM109 (DE3) to obtain the butanologenic E. coli strains BUT1, BUT2, BUT3, BUT1DE, BUT2-DE and BUT3-DE. Finally, pGETS118 was used to transform E. coli JM109 and E. coli JM109 (DE3) to obtain the control strains PGETS118 and PGETS118DE (Table 1). Cell growth and n-butanol production were then investigated.th $=\mathrm{tl} b=$

\section{Growth profile and $n$-butanol production}

Recently, many groups have reported successful nbutanol production in E. coli $[5,6,8]$; a similar approach was previously applied to n-butanol production in $E$. coli carrying the CoA-dependent synthetic pathway, yielding final n-butanol titers of $552 \mathrm{mg} / \mathrm{L}$ to $1.2 \mathrm{~g} / \mathrm{L}[5,6]$. In addition, Shen et al. [8] further improved the strain by using $\mathrm{NADH}$ - and acetyl-CoA-driving forces; the best strain in their study showed high-titer production of n-butanol through in situ product removal. The production of $\mathrm{n}$-butanol has been confirmed to affect host growth.
Compared with the control strains PGETS118 and PGETS118-DE, both recombinant strains BUT1 and BUT1-DE displayed increased n-butanol titer (both reached approximately $73 \mathrm{mg} / \mathrm{L}$ ) after $20 \mathrm{~h}$. Furthermore, $17-21 \%$ reductions in the growth of both strains in PYG medium were observed (Figs. 2 and 3). In addition, after $60 \mathrm{~h}$ of incubation, maximum n-butanol concentrations of $94.6 \mathrm{mg} / \mathrm{L}$ and $95.1 \mathrm{mg} / \mathrm{L}$ were recorded in BUT1 and BUT1-DE cultures, respectively. This result shows that cells at an $\mathrm{OD}_{600}$ value of 1 can convert $1 \mathrm{~g}$ of glucose to $1.75 \mathrm{mg} / \mathrm{L}$ of $\mathrm{n}$-butanol in PYG medium, similar to the rate reported by Inui et al. [6] (1.5 $\mathrm{mg} / \mathrm{L}$ n-butanol/1 g glucose). In the case of PGETS118 and PGETS118-DE, which were monitored as controls, no n-butanol was detected.

\section{Improved tolerance and $\mathbf{n}$-butanol production}

A clostridial strain overexpressing GSH was reported to exhibit improved tolerance and increased n-butanol productivity [30]. Boyarskiy et al. [31] reported increased n-butanol tolerance and production (approximately 35\% increases) through transcriptional feedback regulation of efflux protein expression.

In the present study, we attempted to improve the nbutanol tolerance of butanologenic $E$. coli to further enhance n-butanol production by expressing OmpCTMT. The concentrations of n-butanol found to be inhibitory to $E$. coli in n-butanol production strains (Fig. 2) were consistent with the trends noted in the literature for alcohol toxicity in E. coli [17]. Hence, we examined the normal expression of OmpC-TMT (BUT2, BUT3) in butanologenic E. coli strains, and the results showed that cell growth was still affected by n-butanol. This result is similar to that obtained for the BUT1 strain (Fig. 2a).

However, the BUT2 and BUT3 strains showed similar n-butanol production $(118 \mathrm{mg} / \mathrm{L}$ and $121 \mathrm{mg} / \mathrm{L})$ after
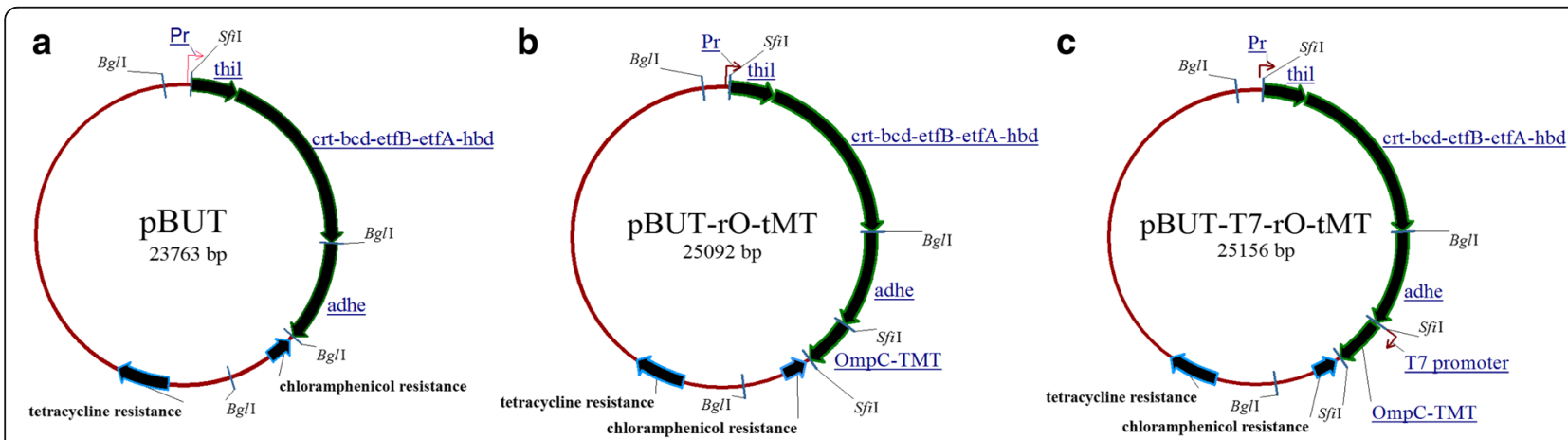

Fig. 1 Structure of the plasmids pBUT, pBUT-rO-tMT and pBUT-T7-rO-tMT. Three recombinant plasmids were derived from the expression vector pGETS118 [29, 74], which contained the Pr promoter. To assemble the butanol synthesis pathway, target gene(s) thil (1.2 kb), crt-bcd-etfB-etfA-hbd cluster (4.8 kb), adhe (2.8 kb) and rO-tMT (1.3 kb) or T7-rO-tMT (1.4 kb) were inserted under the Pr promoter, resulting in pBUT (a), pBUT-rO-tMT (b), and pBUT-T7-rO-tMT (c), respectively. All the plasmids include two antibiotic resistances $\left(T c^{r}\right.$ : tetracycline resistance; $C A T^{r}$ : chloramphenicol resistance) 
Table 1 Strains and plasmids used in this study

\begin{tabular}{|c|c|c|}
\hline $\begin{array}{l}\text { Strains and } \\
\text { plasmids }\end{array}$ & Genotype and description ${ }^{a}$ & $\begin{array}{l}\text { Reference or } \\
\text { source }\end{array}$ \\
\hline \multicolumn{3}{|l|}{ E. coli strains } \\
\hline pET-OmTmt & $\begin{array}{l}\text { E. coli BL21/PET30a, T7 } \\
\text { promoter, f1 origin; ompC-tmt, } \mathrm{Km}^{r}\end{array}$ & {$[27]$} \\
\hline JM109 & $\begin{array}{l}\text { endA1, recA1, gyrA96, thi, hsdR17 } \\
(\text { rk-, mk+), relA1, supE44, } \triangle(\text { lac-proAB), } \\
{\left[F^{\prime} \text { traD36, proAB, laqlaZZM15]. }\right.}\end{array}$ & Promega \\
\hline PGETS118 & E. coli JM109/pGETS118, CAT ${ }^{r}$ & {$[75]$} \\
\hline BUT1 & E. coli JM109/pBUT, CAT ${ }^{r}$ & This work \\
\hline BUT2 & E. coli JM109/pBUT-rO-tMT, CAT ${ }^{r}$ & This work \\
\hline BUT3 & E. coli JM109/pBUT-T7-rO-tMT, CAT ${ }^{r}$ & This work \\
\hline JM109 (DE3) & $\begin{array}{l}\text { JM109+ } \lambda(\text { DE3),Contains an IPTG- } \\
\text { inducible gene for T7 RNA } \\
\text { polymerase }\end{array}$ & Promega \\
\hline PGETS118-DE & E. coli JM109 (DE3)/pGETS118, CAT ${ }^{r}$ & This work \\
\hline BUT1-DE & E. coli JM109 (DE3)/pBUT, CAT ${ }^{r}$ & This work \\
\hline BUT2-DE & $\begin{array}{l}\text { E. coli JM109 (DE3)/pBUT-rO-tMT, } \\
\text { CAT }^{\prime}\end{array}$ & This work \\
\hline BUT3-DE & $\begin{array}{l}\text { E. coli JM109 (DE3)/pBUT-T7-rO-tMT, } \\
\text { CAT }^{r}\end{array}$ & This work \\
\hline \multicolumn{3}{|l|}{ Plasmids } \\
\hline pGETS118 & pGETS1 18Sfil-Pr, TC', CAT ${ }^{r}$ & This work \\
\hline pBUT & $\begin{array}{l}\text { pGETS1 18::thil-crt-bcd-etfAB-hbd-adhe, } \\
\text { TC' }^{r}, \text { CAT }^{r}\end{array}$ & This work \\
\hline pBUT-rO-tMT & pBUT::rbs-ompC-tmt, $T c^{r}, C A T^{r}$ & This work \\
\hline pBUT-T7-rO-tMT & $\begin{array}{l}\text { pBUT:::T7 promoter-ompC-tmt, } \mathrm{TC}^{\mathrm{r}} \text {, } \\
\text { CAT }^{\mathrm{r}}\end{array}$ & This work \\
\hline
\end{tabular}

${ }^{a} \mathrm{CAT}^{r}$, chloramphenicol resistance; $\mathrm{Km}^{r}$, kanamycin resistant

$\mathrm{TC}^{\mathrm{r}}$, tetracycline resistance; $\mathrm{Pr}$, $\mathrm{Pr}$ promoter; $\mathrm{Cl}$, $\mathrm{Cl}$ cassette

$20 \mathrm{~h}$ of incubation (Fig. 3a). After incubation for $60 \mathrm{~h}$, the butanologenic E. coli strains BUT2 and BUT3 showed 1.6-fold and 2.7-fold higher n-butanol production, respectively, than BUT1 $(94.6 \mathrm{mg} / \mathrm{L})$. Notably, BUT3-DE achieved a 1.7-fold increase in n-butanol production compared to that achieved by BUT2-DE after $20 \mathrm{~h}$ of incubation (Fig. 3b). Furthermore, cell growth in the OmpC-TMT-overexpressing butanologenic E. coli (BUT3-DE) was nearly the same as in the control strain (PGETS118-DE) after $60 \mathrm{~h}$ of incubation (Fig. 2b). More importantly, n-butanol production increased nearly 3.4fold compared with that of BUT1-DE $(320 \mathrm{mg} / \mathrm{L})$ and showed a significantly improved conversion rate from glucose to n-butanol ( $4.97 \mathrm{mg} / \mathrm{L} \mathrm{n}$-butanol/1 g glucose) (Fig. 3b). These results suggested that OmpC-TMT overexpression rescued the growth of the butanologenic $E$. coli strains, improved host robustness and increased nbutanol productivity. Our results are consistent with previous reports [28, 30, 31].

In addition, many genes were related to organic solvent tolerance in the E. coli strain, for example, mutant cyclic AMP receptor protein (CRP) [32], overexpression of groESL [33-35], mutant $\Delta$ lon (cell envelope-related gene) [36] and control membranerelated functions (overexpression of ATF, $f a b D, f e o A$ and $\operatorname{srp} A B C)$ [37]. Moreover, Rutherford et al. [17] reported that $\mathrm{n}$-butanol stress-response genes are also involved in many stress responses, such as oxidative stress $(\operatorname{sod} A$, $\operatorname{sod} C$ and $y q h D$ ), heat shock and cell envelope stress (rpoE, clpB, htpG, cpxR and $c p x P$ ). Recently, the tolerance mechanisms of several critical genes have been elucidated. Among them, the downregulated genes $y g h W$ and $y i b T$ were shown to improve $\mathrm{n}$-butanol tolerance due to their regulatory roles in membrane fatty acid composition, while the upregulated genes $g c l$ and $g l c F$ improved cell growth and metabolism by replenishing TCA cycle metabolic intermediates [38]. However, these results reflect the addition of n-butanol to the medium rather than its production by E. coli (Table 2).

Aside from n-butanol, carboxylic acids are attractive biorenewable chemicals, such as fatty acid and aromatic carboxylic acids [39-41]. However, product toxicity is frequently encountered in metabolic engineering, and the toxicity of these carboxylic acids to the microbial biocatalyst appears to limit biocatalyst performance. Strong evidence suggests that membrane damage is the main mechanism of toxicity $[42,43]$, and previous metabolic engineering efforts successfully increased membrane integrity by modulating membrane composition to alter free fatty acid tolerance in E. coli [44-46].

\section{Free radical scavenging ability and membrane integrity test}

Since the cellular membrane is a vital factor that allows cells to acclimate to external stresses and is also one of the components that is strongly affected by organic solvents [47], many studies have proposed that the plasma membrane is the most affected target of organic solvents and plays a significant role in adapting to stress. Additionally, the length of the carbon backbone of the organic solvent can alter the toxicity mechanism; increasing the hydrophobicity of the solvent increases the level of toxicity [48]. Long- and short-chain alcohols cause stress during biofuel production by altering membrane fluidity (also known as Overton's Rule). Ethanol and n-butanol, respectively, decrease and increase membrane fluidity $[47,49,50]$.

Toxicity that causes membrane damage is likely a key limitation for butanologenic microbes to produce butanol, suggesting that our engineering strategy of expressing OmpC-TMT is effective in protecting membrane integrity and scavenging free radicals to improve $\mathrm{n}$ butanol tolerance and production in butanologenic $E$. coli strains.

To test whether OmpC-TMT increased membrane integrity during fermentation, bacteria were stained with DAPI and SYTOX Green nucleic acid stains after $48 \mathrm{~h}$ 


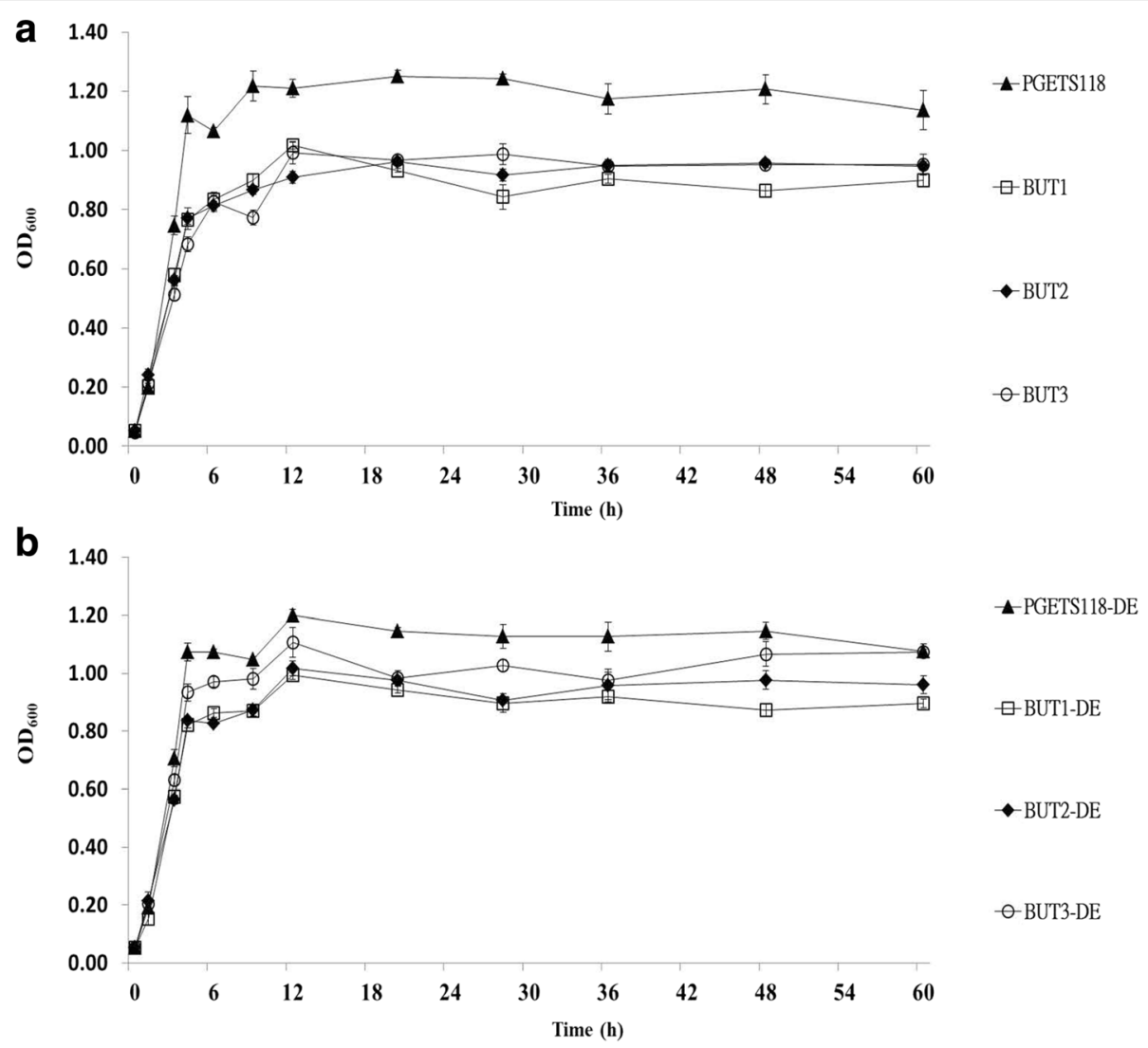

Fig. 2 Growth of engineered $E$. coli strains with various vectors. The engineered $E$. coli were cultured in PYG medium with different expression hosts (a.) JM109 and (b.) JM109 (DE3). All strains were grown under anaerobic conditions at $37^{\circ} \mathrm{C}$ for $60 \mathrm{~h}$. The values and error bars are based on three replicate experiments

of incubation (Fig. 4). Viable bacteria or cells with membrane intact cells were stained and appeared blue only (a, d), whereas nonviable bacteria or cells with damaged membranes would appeared blue and green $(b, e$ and $c$, f). The ratio of cell membrane damage was determined as the number of SYTOX stain-labeled bacteria cells/the number of DAPI stain-labeled bacteria cells and was $1.57 \% \pm 0.33 \%, 48.59 \% \pm 5.98 \%$, and $19.69 \% \pm 4.16 \%$, for PGETS118-DE, BUT1-DE and BUT3-DE, respectively. The engineered E. coli strain BUT3-DE, expressing the outer-membrane fusion protein OmpC-TMT, exhibited better membrane integrity than that of $E$. coli strain BUT1-DE. These results clarified the relationship between membrane integrity and butanol resistance.

MTs are antioxidants that scavenge radicals, and alcohols are known to cause oxidative stress in E. coli [51]. In the present study, we examined the ability of OmpCTMT to scavenge free radicals when the host cells were producing n-butanol. We then analyzed the ROS content of the cells using 5(6)-carboxy-2', 7'- dichlorodihydrofluorescein diacetate (carboxy- $\mathrm{H}_{2}$ DCFDA). During the first $60 \mathrm{~h}$ of incubation, the levels of free radicals in all strains increased with increasing concentration of n-butanol, as shown by the increasing levels of fluorescence (Fig. 5a). After fermentation for 20 h, BUT3DE displayed 2-fold higher free radical content and 2.8-fold greater n-butanol production than BUT1-DE (Figs. 3b and 5a). In contrast, both PGETS118-DE and BUT1-DE had lower levels of radicals than the OmpC-TMT-expressing strains, because no or less $n$ butanol was produced. Moreover, we examined the capacity for OmpC-TMT to scavenge free radicals when the host cells produced n-butanol. As shown in Fig. 3b, BUT3-DE $(320.24 \mathrm{mg} / \mathrm{L})$ produced more $\mathrm{n}$ butanol than BUT2-DE $(151.03 \mathrm{mg} / \mathrm{L})$. However, both BUT2-DE and BUT3-DE produced similarly large amounts of ROS after $60 \mathrm{~h}$ of incubation (Fig. 5a). The effect of $n$-butanol on each strain was defined as [specific fluorescence of each strain (A535/A600)/(n-butanol production by each strain)]. BUT3-DE showed approximately 2 -fold higher free radical scavenging capacity (25.27) than BUT1-DE (54.07) and BUT2-DE (51.25) (Fig. 5b). Interestingly, this result is consistent with the result from the membrane integrity test. 

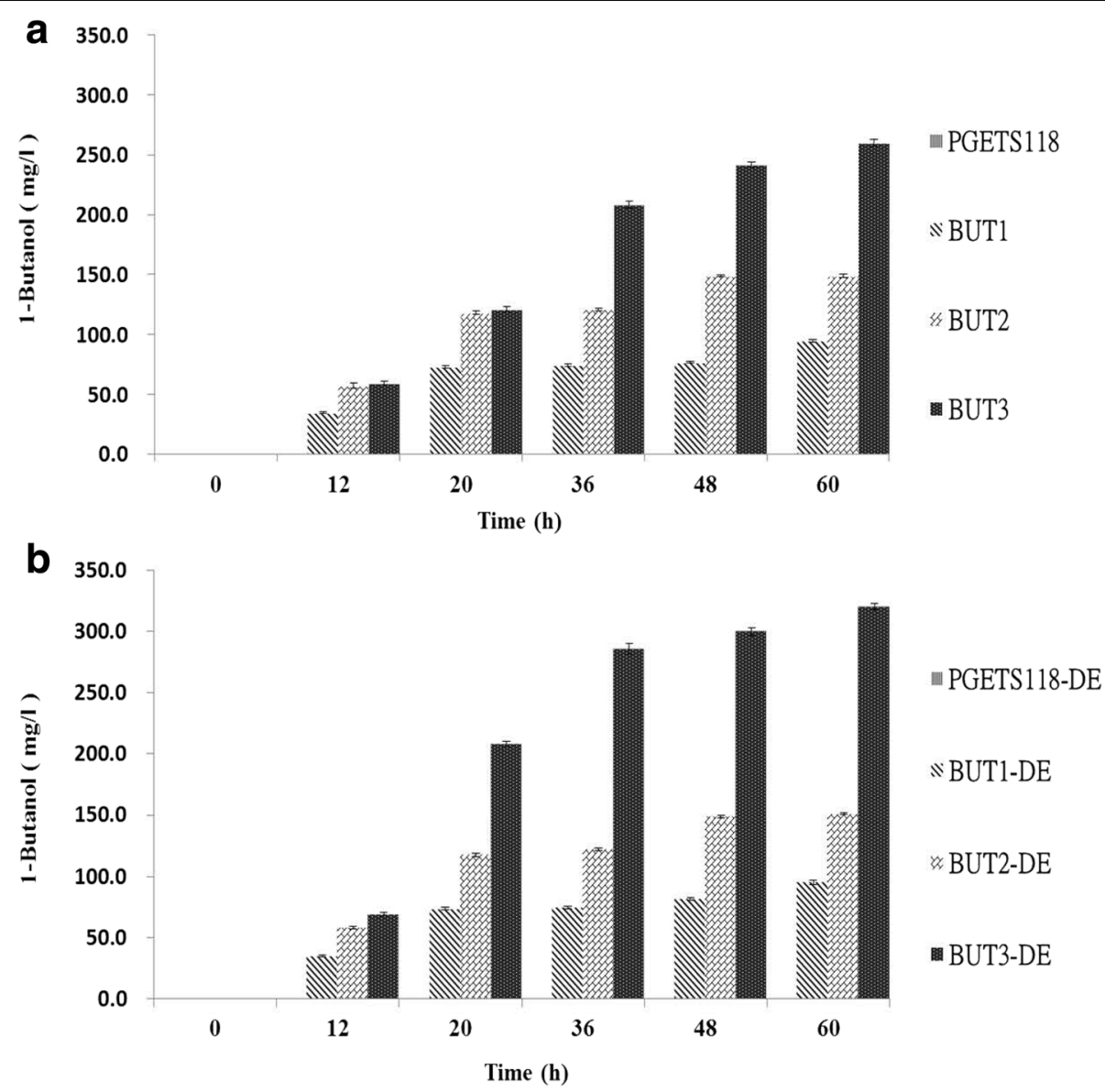

Fig. 3 Comparison of n-butanol production in E. coli containing various vectors. The engineered E. coli were cultured in PYG medium with different expression hosts (a.) JM109 and (b.) JM109 (DE3). All strains were grown under anaerobic conditions at $37^{\circ} \mathrm{C}$ for $60 \mathrm{~h}$. The values and error bars are based on three replicate experiments

Table 2 Engineering strategies to improve butanol tolerance and production in E. coli

\begin{tabular}{|c|c|c|c|c|c|c|}
\hline \multicolumn{4}{|c|}{ Butanol tolerance } & \multicolumn{3}{|l|}{ Butanol production } \\
\hline & Strategy & Tolerance (v/v) & Reference & Strategy & Production (mg/l) & Reference \\
\hline 1 & Overexpression of ompC-tmt & From 1.50 to $2.00 \%$ & {$[28]$} & $\begin{array}{l}\text { thil, crt, bcd, etfA, etfB, hbd, adhe, } \\
\text { ompC-tmt }\end{array}$ & $320 \mathrm{mg} / \mathrm{l}$ & This work \\
\hline 2 & N.D. & N.D. & N.D. & $\begin{array}{l}\text { atoB, crt, bcd, etfAB, hbd, adhe, } \triangle a d h E, \\
\Delta / d h A, \Delta f r d B C, \Delta f n r, \Delta p t a\end{array}$ & $552 \mathrm{mg} / \mathrm{l}$ & {$[5]$} \\
\hline 3 & N.D. & N.D. & N.D. & $\begin{array}{l}\text { thil, hbd, } c r t, b c d \text {, etfA, etfB, adhe, } \\
\text { high cell density }\end{array}$ & $1,200 \mathrm{mg} / \mathrm{l}$ & {$[6]$} \\
\hline 4 & $\begin{array}{l}\text { Overexpression of ATF, fabD, feoA } \\
\text { and srpABC }\end{array}$ & From 1.50 to $2.00 \%$ & {$[38]$} & N.D. & N.D. & N.D. \\
\hline 5 & $\begin{array}{l}\text { double disruptions of prov and } \\
\text { marR Mutation of lon }\end{array}$ & From 1.00 to $2.00 \%$ & {$[37]$} & N.D. & N.D. & N.D. \\
\hline 6 & Overexpression of groESL & From 0.75 to $1.00 \%$ & {$[34]$} & N.D. & N.D. & N.D. \\
\hline 7 & $\begin{array}{l}\text { Mutation of cyclic AMP receptor } \\
\text { protein (CRP) }\end{array}$ & From 0.80 to $1.20 \%$ & [33] & N.D. & N.D. & N.D. \\
\hline
\end{tabular}




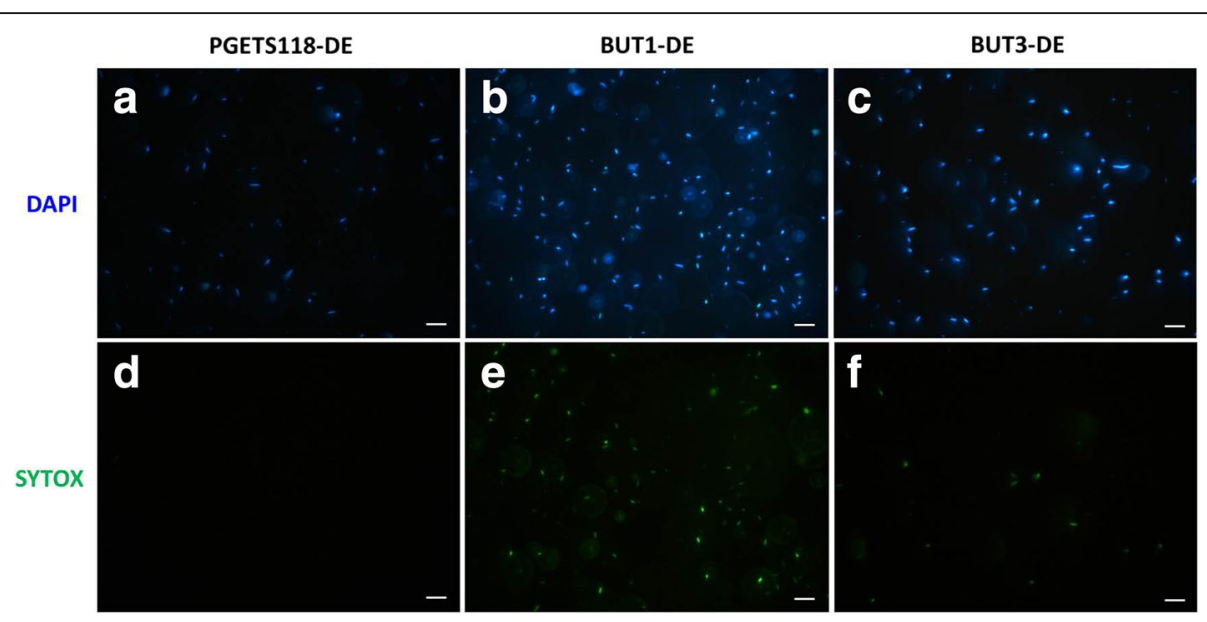

Fig. 4 Fluorescence microscopy of DAPI- and SYTOX Green-labeled bacteria. Three kinds of the engineered E. coli strains (PGETS118-DE, BUT1-DE and BUT3-DE) were cultured in PYG medium and incubated at $37^{\circ} \mathrm{C}$ for $48 \mathrm{~h}$. All bacteria were stained with both DAPI and SYTOX Green nucleic acid stains. The staining patterns of E. coli labeled with $1 \mu \mathrm{g} / \mathrm{ml} \mathrm{DAPI}$ and $5 \mu \mathrm{M}$ SYTOX Green were compared via fluorescence microscopy. Viable bacteria or membrane-intact cells were stained and appear blue only $(\mathbf{a}, \mathbf{d})$. Nonviable bacteria or membrane-damaged cells are stained and appear blue and green (b, e and $\mathbf{c}, \mathbf{f}$ ). Scale bar $=5 \mu \mathrm{m}$. Measurements were obtained from three replicate experiments

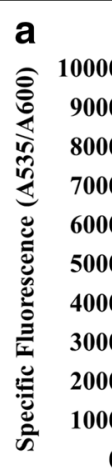

b

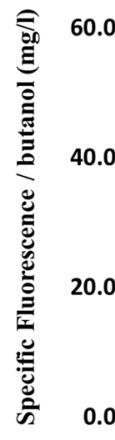

\section{Reactive oxygen species assay}

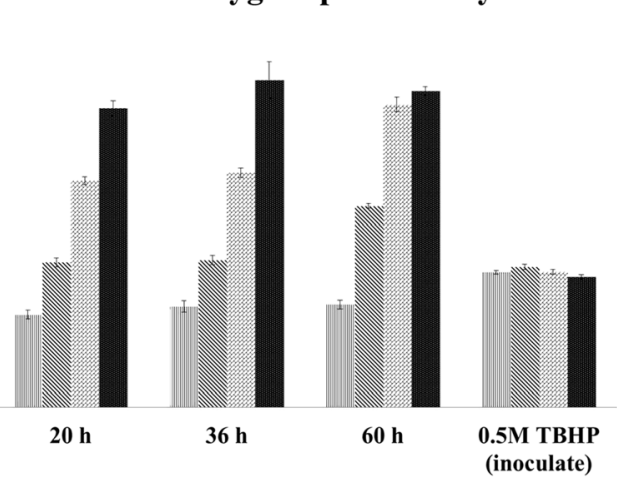

므 PGETS118-DE

* BUT1-DE

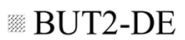

- BUT3-DE

* BUT1-DE

簽BUT2-DE

- BUT3-DE

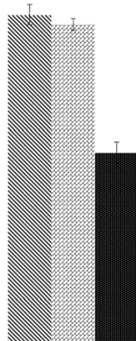

$36 \mathrm{~h}$

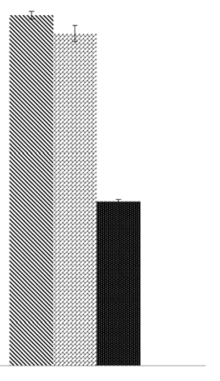

$60 \mathrm{~h}$

Fig. 5 Quantitative assay of intracellular reactive oxygen species in different engineered $E$. coli strains. a The levels of free radicals in all strains. $\mathbf{b}$ The effect of n-butanol on each strain. The optical density at $600 \mathrm{~nm}$ and fluorescence at $535 \mathrm{~nm}$ of the engineered $E$. coli strains were measured for cells cultured in PYG medium for different times $(0 \mathrm{~h}, 20 \mathrm{~h}, 36 \mathrm{~h}, 60 \mathrm{~h})$ at $37^{\circ} \mathrm{C}$. "TBHP" represents the positive control in which strains were treated with $0.5 \mathrm{M}$ tert-butyl hydroperoxide, which is known a stressor, after inoculation to produce intracellular $\mathrm{H}_{2} \mathrm{O}_{2}$. Measurements were obtained from three replicate experiments 
Therefore, OmpC-TMT overexpression enhanced nbutanol production by lowering the levels of free radicals and increasing membrane integrity.

\section{Expression profiles of $\mathrm{n}$-butanol and tolerance genes in E. coli}

As shown in Table 3 , the relative expression of the four genetic regions (thil, crt-bcd-etfB-etfA-hbd, adhe, ompC-tmt) with respect to the $\operatorname{rrs} A$ gene in the two sample types (control and experimental) for three cases (1. BUT1-DE and BUT2-DE; 2. BUT1-DE and BUT3-DE; and 3. BUT2-DE and BUT3-DE) was determined using qPCR assays. In this study, differential expression was observed between the OmpC-tMT strains and the control. In case 1, expression of the four genetic regions was lower in the control (BUT1DE). BUT1-DE expressed ompC-tmt, but we did not introduce this gene into the plasmid. This phenomenon was observed in another study in which an E. coli strain was observed to tolerate solvents through the upregulation of $\mathrm{OmpC}[38,52]$. Therefore, gene expression may be derived from the host. Nevertheless, BUT2-DE exhibited high free radical scavenging capacity and high n-butanol yield compared with BUT1-DE (Fig. 5b), indicating that lower oxidative stress and higher n-butanol production may result from TMT protein expression. In case 2 with BUT3-DE, the expression of n-butanol production genes was still lower than in the control (BUT1-DE), but the ompC-tmt gene showed high expression due to the T7 promoter. Hence, we examined the ability of BUT3-DE to scavenge free radicals, and the result showed BUT3-DE had the greatest ability to reduce oxidative stress and the best n-butanol production (Figs. 3b and 5a). Finally, in case 3, BUT3-DE expressed more n-butanol production genes than BUT2-DE. These results again suggest that OmpCTMT overexpression improved the robustness of the host to achieve better solvent production by decreasing the production of ROS.

\section{Transcriptomic analysis in engineered $E$. coli}

Understanding the membrane stress response to solvents and alcohols may facilitate the engineering of microorganisms for improved toxin tolerance. Therefore, the stress responses of organisms such as $E$. coli to ethanol exposure have been widely studied [53-55], and information from these studies has been successfully adapted to engineer improved ethanologenic hosts [5659]. Although both strains appeared to grow into stationary phase after $36 \mathrm{~h}$ of incubation, meaningful increases $(P$-value $<0.01)$ in their butanol titers were still observed after $48 \mathrm{~h}$ (Fig. 3b, BUT1-DE: $74.49 \pm 1.09 \mathrm{mg} /$ $\mathrm{l}(36 \mathrm{~h}), 81.55 \pm 1.15 \mathrm{mg} / \mathrm{l}(48 \mathrm{~h})$ and $95.19 \pm 1.62 \mathrm{mg} / \mathrm{l}$ (60 h); and BUT3-DE: $285.94 \pm 4.10 \mathrm{mg} / \mathrm{l}$ (36 h), 299.81 $\pm 2.92 \mathrm{mg} / \mathrm{l}(48 \mathrm{~h})$ and $320.24 \pm 2.56 \mathrm{mg} / \mathrm{l}(60 \mathrm{~h}))$. Meanwhile, as shown by the levels of fluorescence after $36 \mathrm{~h}$ and $60 \mathrm{~h}$, ROS levels increased in BUT1-DE but decreased in BUT3-DE (Fig. 5a). Because BUT3-DE and BUT1-DE exhibited opposite changes in oxidative stress after $60 \mathrm{~h}$ (Fig. 5b), the effects of OmpC-TMT expression on butanologenic $E$. coli strains were explored via transcriptomic analysis using next-generation sequencing technology. Among the differentially expressed genes, a total of 147 genes (Additional file 1: Table S3), 73 upregulated and 74 downregulated genes in BUT3DE vs. Control (BUT1-DE) met the selection criteria of (1) genes that changed by fragments per kilobase of exon per million fragments mapped reads $($ FPKM $)>0.3$ [60] and (2) a minimum of a twofold change in normalized read counts between groups. The $\mathrm{P}$-value $(\mathrm{P}<0.05)$ was estimated for each gene and was corrected for multiple testing using the Benjamini-Hochberg correction. The fold-change was used to partition the genes into up- and downregulated groups. Then, all the significantly expressed genes were subjected to KEGG (Kyoto Encyclopedia of Genes and Genomes) pathway analysis (database from KEGG E. coli str. K12 substr. W3110). We identified five significant KEGG pathways in the BUT3-DE OmpC-TMT-expressing strain, including oxidative phosphorylation (4 genes), fructose and mannose metabolism (3 genes), ribosome (4 genes), glycolysis/gluconeogenesis (2 genes) and nicotinate and nicotinamide metabolism (2 genes). All 15 significantly expressed genes were compared between BUT3-DE and BUT1-DE (Table 4). We observed 4 downregulated genes (nuol, nuoG, nuoF and nuoC) in oxidative phosphorylation (Table 4). The nuo operon encodes the

Table 3 Real-time RT-PCR analysis

\begin{tabular}{|c|c|c|c|c|}
\hline \multirow{2}{*}{$\begin{array}{l}\text { Sample } \\
\text { Experimental/Control }\end{array}$} & \multicolumn{4}{|c|}{ Gene expression log2 fold change ${ }^{a}\left[\log 2\left(2^{-\Delta \Delta C T}\right.\right.$ (Exp-Control) $\left.)\right]$} \\
\hline & thil & crt-bcd-etfB-etfA-hbd & adhe & ompC-tmt \\
\hline BUT2-DE/BUT1-DE & $-7.79 \pm 0.02$ & $-8.64 \pm 0.08$ & $-7.72 \pm 0.06$ & $-1.40 \pm 0.02$ \\
\hline BUT3-DE/BUT1-DE & $-3.09 \pm 0.12$ & $-4.14 \pm 0.69$ & $-0.76 \pm 0.10$ & $2.84 \pm 0.09$ \\
\hline BUT3-DE/BUT2-DE & $4.70 \pm 0.11$ & $4.50 \pm 0.68$ & $6.96 \pm 0.16$ & $4.24 \pm 0.08$ \\
\hline
\end{tabular}

${ }^{a}$ The values represent ratio of gene expression log 2 fold change and are means \pm standard deviations from three independent experiments (Gene expression log2 fold change: $>0$, ie. Up regulation; $=0$, ie. No change; $<0$, ie. Down regulation) 
Table 4 KEGG biological pathways for significantly expressed genes ${ }^{a}$

\begin{tabular}{|c|c|c|c|}
\hline Groups & Gene & Expression difference $^{b}$ & Description \\
\hline \multirow[t]{4}{*}{ Oxidative phosphorylation } & nuol & $-1.88 \downarrow$ & NADH:ubiquinone oxidoreductase, chain I \\
\hline & nuoG & $-1.71 \downarrow$ & NADH:ubiquinone oxidoreductase, chain G \\
\hline & nuof & $-1.49 \downarrow$ & NADH:ubiquinone oxidoreductase, chain F \\
\hline & nuoc & $-1.35 \downarrow$ & NADH:ubiquinone oxidoreductase, fused CD subunit \\
\hline \multirow[t]{3}{*}{ Fructose and mannose metabolism } & fucA & $2.26 \uparrow$ & L-fuculose-1-phosphate aldolase \\
\hline & srle & $1.63 \uparrow$ & glucitol/sorbitol-specific enzyme IIB component of PTS \\
\hline & srlA & $2.78 \uparrow$ & glucitol/sorbitol-specific enzyme IIC component of PTS \\
\hline \multirow[t]{4}{*}{ Ribosome } & $r p / A$ & $-1.32 \downarrow$ & $50 S$ ribosomal subunit protein L1 \\
\hline & rpsF & $-1.42 \downarrow$ & $30 S$ ribosomal subunit protein S6 \\
\hline & rpmF & $-2.22 \downarrow$ & $50 S$ ribosomal subunit protein $\mathrm{L} 32$ \\
\hline & $r p l l$ & $-1.34 \downarrow$ & $50 S$ ribosomal subunit protein L9 \\
\hline \multirow[t]{2}{*}{ Glycolysis/Gluconeogenesis } & $p f k B$ & $-1.75 \downarrow$ & 6-phosphofructokinase II \\
\hline & pgm & $-1.44 \downarrow$ & phosphoglucomutase \\
\hline \multirow[t]{2}{*}{ Nicotinate and nicotinamide metabolism } & $y j j G$ & $1.24 \uparrow$ & dUMP phosphatase \\
\hline & pntA & $-1.45 \downarrow$ & pyridine nucleotide transhydrogenase, alpha subunit \\
\hline
\end{tabular}

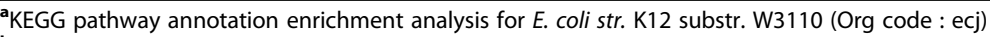

${ }^{\mathbf{b}}$ Genes that changed by FPKM $>0.3$ and $\geqq 2$-fold differences between BUT3-DE vs. BUT1-DE

$\uparrow$ Represents up-regulated genes; $\downarrow$ represents down-regulated genes

$\mathrm{NADH}$ ubiquinone oxidoreductase (complex I) that couples the transfer of electrons from NADH to ubiquinone with the translocation of protons across the cytoplasmic membrane and forms an integral part of oxidative phosphorylation [61]. Quinones are electron carriers with an isoprenoid side chain that anchors them to the membrane; they function as the primary electron carriers for respiration and are thought to regulate the ArcA-ArcB two-component system in response to the cellular redox state [62-64].

However, the past results showed that isobutanol disrupts the cell membrane, leading to quinone malfunction, which results in the release of quinone inhibition on $\mathrm{ArcB}$ and the subsequent autophosphorylation of ArcB and activation of ArcA, which adapts cellular metabolism for growth with decreased respiratory efficiency, such as downregulation of NADH dehydrogenase I (nuo operon) or upregulation of cytochrome d oxidase (cydAB operon) [16]. This hypothesis coincides with our results. In addition, microbial fermentation pathways involve many redox reactions, which usually require $\mathrm{NADH}$ and $\mathrm{NAD}^{+}$ as cofactors. However, in the clostridial synthetic pathway, the synthesis of n-butanol from glucose can cause an $\mathrm{NADH} / \mathrm{NAD}^{+}$redox imbalance because more NADH is required in the synthetic pathway than is generated in the glycolytic pathway [65]. Therefore, compared with the control strain, in the modified strain, a number of upregulated genes, such as $f u c A, s r l E$ and $s r l A$, may help supplement metabolic intermediates for fructose and mannose metabolism to generate NADH and assist in regulating
$\mathrm{NADH} / \mathrm{NAD}^{+}$redox $[66,67]$. These results suggested that maintaining the redox balance of NADH and $\mathrm{NAD}^{+}$is a key to ensure the continued operation of cellular metabolism under n-butanol fermentation. The same strategy was used in previous research $[8$, 65]. Moreover, isobutanol disrupts quinone/quinol function, resulting in the malfunction of NADH ubiquinone oxidoreductase (complex I), which would diminish the ability to convert NADH to $\mathrm{NAD}^{+}$and generate the proton motive force (PMF) [16]. This process may affect the biosynthesis of ATP in the cell. We also found that two genes $(p f k B, p g m)$ involved in glycolysis/gluconeogenesis were downregulated. One possible explanation is that the downregulation of $p f k B$, which encodes 6phosphofructokinase II, results in the decreased conversion of fructose-6-phosphate (F6P) to fructose-1, 6biphosphate, thereby reducing the consumption of ATP. Additionally, pgm encodes phosphoglucomutase and facilitates the interconversion of glucose-1phosphate and glucose-6-phosphate (G6P). One possible explanation for the downregulation of $\mathrm{pgm}$ is that glucose-1-phosphate is further converted to ADPglucose by ATP depletion. This result indicated that BUT3-DE tried to reduce ATP consumption following $\mathrm{NADH}$ dehydrogenase I malfunction. Moreover, both the $p f k B$ and $p g m$ genes were downregulated, which may result in the accumulation of G6P and F6P. Both G6P and F6P, as starting metabolites for the pentose phosphate pathway, produce precursors and provide a major source of NADPH for biosynthesis, which is 
involved in most of reductive pathways [68, 69]. However, previous studies show the energy-dependent reduction of $\mathrm{NADP}^{+}$with $\mathrm{NADH}$ by PntAB, but increased NADPH formation will downregulate pntA for genetic and environmental manipulation [70].

In general, cells exposed to n-butanol show elevated levels of oxidative stress, and many oxidative-related genes have been identified as being significantly upregulated [17]. However, in our case, although BUT3-DE showed elevated butanol production and higher radical scavenging capacity than BUT1-DE (Figs. 3b and 5b), we did not detect significant expression of oxidative stressrelated genes. In fact, our analysis found that genes related to oxidative stress $(\operatorname{sod} A)$ and cell envelope stress $(c p x P)$ were expressed (Additional file 1: Table S3). Meanwhile, KEGG pathway analysis revealed no significant differences between BUT1-DE and BUT3-DE with respect to these genes, and thus was not included in Table 4. Given that BUT1-DE experienced higher oxidative stress than BUT3-DE (Fig. 5b), these results suggest that OmpC-TMT overexpression decreased ROS production, as well as the expression of oxidative stressrelated genes, in BUT3-DE.

\section{Conclusions}

This study uses a novel approach to develop E. coli strains that express both the n-butanol synthesis pathway and membrane-targeted MTs to improve cell fermentation via ROS scavenging. OmpC-TMT was able to decrease the production of free radicals and to improve host robustness during fermentation. Furthermore, a balanced intracellular redox state in microbes is recognized as essential to ensure the efficient production of fermentation products. Unfortunately, our studies suggest that although OmpCTMT expression increased n-butanol production compared to that of the control strain, the accumulation of fermented products (e.g., n-butanol) in the cell or external environment cause malfunctions in the NADH and ATP synthesis system. Therefore, this fermentation system requires further improvement. In principle, the expression of membrane-targeted TMT has the potential to improve the alcohol fermentation bioprocess and may also serve as a practical strategy for the construction of platform E. coli strains for biofuel production.

\section{Methods}

\section{Reagents}

All chemicals and reagents were purchased from SigmaAldrich Co., USA, unless otherwise noted. The reagents, when available, were molecular biology grade. All solutions were prepared using these reagents and sterile distilled water.

\section{Construction of plasmids via the OGAB method}

The OGAB method was described previously [29]. The primer sequences used in this study are listed in Additional file 2: Table S1. To construct an expression plasmid containing the clostridial n-butanol synthesis pathway, thil $(1.2 \mathrm{~kb})$ and the crt-bcd-etfB-etfA-hbd cluster $(4.8 \mathrm{~kb})$ were first amplified from the genomic DNA of C. acetobutylicum ATCC824, and the adhel $(2.7 \mathrm{~kb})$ gene was amplified from $C$. acetobutylicum ATCC824 megaplasmid pSOL1. ompC-tmt (1.3 kb) was amplified from pET-OmTmt [27]. The PCR products were subcloned into the yT\&A cloning vector (YEASTERN) and confirmed by DNA sequencing. All PCR products were digested and then assembled as one transcriptional unit into pGETS118 in a polycistronic manner using the OGAB method, resulting in pBUT, pBUT-rO-tMT and pBUT-T7-rO-tMT (Fig. 1). All genes and an assembly vector were prepared as DNA fragments with arbitrary 3'-nucleotide protrusions that allowed the genes to be linked together in a specific order and direction. The protrusions were generated by type II restriction endonucleases that recognize two separate recognition sites, such as Sfil, which recognizes 5'-GGCCANNNAGGCC-3', where $\mathrm{N}$ is any nucleotide in a random sequence. SfiI and BglI were chosen in this study since SfiI and BglI sites are absent in the relevant genes and vectors. The constructed plasmids were transferred into E. coli JM109 and JM109 (DE3) to obtain the recombinant E. coli strains BUT1, BUT2, BUT3, BUT1-DE, BUT2-DE and BUT3-DE (Table 1) and to assay the production of n-butanol.

\section{Bacterial strains, culture media and growth conditions}

MT-expressing engineered strains, protein expression and their locations in recombinants $E$. coli hosts were confirmed in our previous study [27]. All batch cultures were grown at $37{ }^{\circ} \mathrm{C}$ in a rotary shaker at $200 \mathrm{rpm}$. Batch cultures were grown in $150 \mathrm{~mL}$ PYG medium under anaerobic conditions (per liter: $5 \mathrm{~g}$ of peptone, $10 \mathrm{~g}$ of yeast extract, $60 \mathrm{~g}$ of glucose, $5 \mathrm{~g}$ of tryptone, $40 \mathrm{mg}$ of $\mathrm{K}_{2} \mathrm{HPO}_{4}, 19.2 \mathrm{mg}$ of $\mathrm{MgSO}_{4} .7$ $\left(\mathrm{H}_{2} \mathrm{O}\right), 8 \mathrm{mg}$ of $\mathrm{CaCl}_{2}, 40 \mathrm{mg}$ of $\mathrm{KH}_{2} \mathrm{PO}_{4}, 0.4 \mathrm{~g}$ of $\mathrm{NaHCO}_{3}, 80 \mathrm{mg}$ of $\mathrm{NaCl}$ and $1.1 \mathrm{mg}$ of $\mathrm{FeSO}_{4} .7 \mathrm{H}_{2} \mathrm{O}$ ) or in M9 (AMRESCO-J863) media. Each engineered $E$. coli strain, including PGETS118, BUT1, BUT2, BUT3, PGETS118-DE, BUT1-DE, BUT2-DE, and BUT3-DE (Table 1), was grown in medium supplemented with $50 \mu \mathrm{g} / \mathrm{mL}$ chloramphenicol. When the culture density reached OD 0.6, isopropyl- $\beta$-D-thiogalactopyranoside (IPTG) was added to a final culture concentration of $0.6 \mathrm{mM}$. After $12 \mathrm{~h}$ of incubation, cells were harvested for ROS and n-butanol production experiments. All solvent concentrations in media are reported as $\mathrm{mg} / \mathrm{L}$. 


\section{Analytical methods}

Cell density was measured at $600 \mathrm{~nm}$ using a UV-vis spectrophotometer (GENESYS 10S, Thermo Scientific, USA). Fermentation samples were analyzed by gas chromatography (GC) on an Agilent 7890A equipped with a split/splitless injector, flame ionization detector, and a DP-FFAP capillary column $(30 \mathrm{~m}, 0.32 \mathrm{~mm}$ i.d., $0.25 \mu \mathrm{m}$ film thickness). The temperatures of the injector and detector were both maintained at $225{ }^{\circ} \mathrm{C}$. The temperature profile of the column oven was as follows: (i) initial hold at $50{ }^{\circ} \mathrm{C}$ for $4 \mathrm{~min}$, increase to $100{ }^{\circ} \mathrm{C}$ at $20{ }^{\circ} \mathrm{C} / \mathrm{min}$ and hold for $1 \mathrm{~min}$; (ii) increase to $170{ }^{\circ} \mathrm{C}$ at $30{ }^{\circ} \mathrm{C} / \mathrm{min}$ and hold for $2.5 \mathrm{~min}$; and (iii) increase to $220^{\circ} \mathrm{C}$ at $20^{\circ} \mathrm{C} / \mathrm{min}$ and hold for $4 \mathrm{~min}$. Nitrogen gas was used as the carrier gas. Split injection mode was used, with a split ratio of 1:10.

\section{Reactive oxygen species detected by carboxy- $\mathrm{H}_{2}$ DCFDA under $\mathbf{n}$-butanol stress}

The engineered E. coli strains were cultured in PYG medium, and different concentrations of n-butanol were produced after $0,20,36$ and $60 \mathrm{~h}$ of incubation. Aliquots of $100 \mu \mathrm{L}$ of the cultured strains were resuspended in $5 \mathrm{~mL}$ of $\mathrm{M} 9$ medium, and $140 \mu \mathrm{L}$ of each diluted sample was transferred to a 96-well plate, followed by incubation at $37{ }^{\circ} \mathrm{C}$. The assay method was adapted from a previous study [17]. All samples were treated with $10 \mu \mathrm{L}$ of $25 \mathrm{mM}$ carboxy$\mathrm{H}_{2}$ DCFDA (Invitrogen, Co., Carlsbad, CA) and incubated at $37{ }^{\circ} \mathrm{C}$ for $15 \mathrm{~min}$. The optical density at $600 \mathrm{~nm}$ and the fluorescence excitation/emission at $535 / 600 \mathrm{~nm}$ of each sample were measured on a plate reader. Tert-butyl hydroperoxide (TBHP) (Invitrogen, Carlsbad, CA) is a known stressor that produces intracellular $\mathrm{H}_{2} \mathrm{O}_{2}$; a set of positive controls for the ROS assay were prepared with strains cultured after inoculation and were treated as above, except with an initial dilution step with $10 \mu \mathrm{L}$ of $7.78 \mathrm{M}$ TBHP.

\section{Staining of bacterial suspensions with DAPI and SYTOX Green}

Bacterial suspensions containing either $1.0 \times 10^{6}$ or $1.2 \times 10^{6}$ organisms $/ \mathrm{mL}$ were stained with $0.5 \mu \mathrm{M}$ SYTOX Green and $1 \mu \mathrm{g} / \mathrm{ml}$ DAPI. The fluorescence emissions from $E$. coli were compared with the background fluorescence of each stain alone at the optimal excitation wavelength for each nucleic acid stain (DAPI, 358 nm; SYTOX Green, $504 \mathrm{~nm}$ ). The mixture of cells and DAPI was incubated at $37{ }^{\circ} \mathrm{C}$ for $10 \mathrm{~min}$, and the cells were washed twice with TBS buffer (pH 7.6). Next, the DAPI-stained cells were stained with SYTOX Green nucleic acid again, incubated at $37{ }^{\circ} \mathrm{C}$ for $10 \mathrm{~min}$, and washed three times with TBS buffer (pH 7.6). Fluorescence was observed on a Nikon ECLIPSE 80i (Nikon, Tokyo, Japan).

\section{Next-generation sequencing and analysis}

After $60 \mathrm{~h}$ of incubation, total RNA was isolated from both butanologenic strains (BUT1-DE and BUT3-DE) for next-generation sequencing (RNA-Seq), which was performed by Welgene Biotech Co., Ltd. (Taipei, Taiwan). Total RNA was extracted using the Trizol $^{\circ}$ Reagent (Invitrogen, USA) according to the manufacturer's instructions. Purified RNA was quantified at $260 \mathrm{~nm}$ using an ND-1000 spectrophotometer (Nanodrop Technology, USA) and was qualitatively analyzed using a Bioanalyzer 2100 (Agilent Technology, USA) with an RNA 6000 labchip kit (Agilent Technologies, USA). All procedures were performed according to the Illumina protocol. For all samples, library construction was performed using TruSeq RNA Sample Prep Kits v2 for 75 bp (Single-End) sequencing and the Solexa platform (Illumina Inc.). Sequences were directly determined using sequencing-by-synthesis technology via the TruSeq SBS Kit. Raw sequences were obtained from the Illumina Pipeline software bcl2fastq v2.0 and were expected to generate $10 \mathrm{M}$ (million reads or $\mathrm{Gb}$ ) per sample. The generated sequences were filtered to obtain qualified reads. Trimmomatics was implemented to trim or remove reads according to the quality score [71]. Qualified reads after filtering low-quality data were analyzed using TopHat/ Cufflinks for gene expression estimation [72]. The gene expression level was calculated as FPKM (fragments per kilobase of transcript per million mapped reads). For differential expression analysis, CummeRbund was employed to perform statistical analysis of the gene expression profiles. The reference genome and gene annotations were retrieved from the Ensembl database for E. coli str. K-12 substr. W3110. The cuffdiff tool from the cufflinks package was run to calculate expression changes and the associated P-values for each gene between strain BUT1-DE (control) and strain BUT3-DE (Table 1) after $60 \mathrm{~h}$ of incubation. The output files of cuffdiff were annotated by adding gene functional descriptions. KEGG term enrichment analysis and fold-change enrichment for the gene lists of significantly upregulated and downregulated genes in two butanologenic strains were performed. KEGG pathways were analyzed using NIH DAVID Bioinformatics Resources 6.7 [73] to identify the regulated biological themes.

\section{Quantitative Real-Time PCR Analysis}

Total RNA for quantitative reverse transcriptase PCR (qPCR) was extracted as described for next-generation sequencing and analysis. Two-step quantitative real-time PCR (qPCR) was conducted using LightCycler ${ }^{\circledR}$ FastStart DNA Master PLUS SYBR Green I (Roche Life Science) 
on a Light Cycler 480 Real-Time PCR 3System (Roche Co., Germany) and was performed by Welgene Biotech Co., Ltd. (Taipei, Taiwan). The four genetic regions involved in n-butanol production pathway (thil, crt-bcdetfB-etfA-hbd, adhe) and ROS-targeted scavenging (ompC-tmt) were analyzed. R16s (rrsA gene) was used as a reference in all analyses. The primers are provided in Additional file 3: Table S2 in the supplemental material. For the relative quantification of gene expression, the comparative CT method was employed. The averaged $\mathrm{CT}$ was subtracted from the corresponding averaged r16S value for each sample; resulting in $\Delta C T$. $\Delta \Delta C T$ was obtained by subtracting the average control $\Delta \mathrm{CT}$ value from the average experimental $\Delta \mathrm{CT}$. The fold increase was determined by calculating $\log 2\left(2^{-\Delta \Delta C T}\right)$ for the experimental vs. control samples.

\section{Additional files}

Additional file 1: Table S3. List of the 147 differentially expressed genes. In all 147 differentially expressed genes, including 132 down- and 4 up-regulated, were detected in the BUT3-DE, compared to the BUT1DE. (DOCX $37 \mathrm{~kb}$ )

Additional file 2: Table S1. Primes used for OGAB method. The primer sequences used in this study are listed. (DOCX $23 \mathrm{~kb}$ )

Additional file 3: Table S2. Primes used for $q P C R$. The primer sequences used in this study are listed. (DOCX $22 \mathrm{~kb}$ )

\section{Abbreviations}

PYG: Medium containing peptone, yeast extract and glucose.; ROS: Reactive oxygen species

\section{Acknowledgements}

We thank Jian-Rong Li and Tzu-Hang Yuan for help with the next-generation sequencing data analysis and in gathering information.

\section{Funding}

This work was supported by grants (MOST 104-2621-M-005-003-MY3) from the National Science Council, Taiwan.

\section{Availability of data and materials}

The datasets supporting the conclusions of this article are included within the manuscript and its additional files. The data set supporting the results of this article are available in the NCBI Sequence Read Archive (http:// www.ncbi.nlm.nih.gov/sra/) repositories, SRR5352318, and SRR5352319.

\section{Authors' contributions}

WCC performed the experiments, analyzed the data and drafted the manuscript. KHL performed some of the experimental work. KHL contributed to data interpretation. WCC and KHL wrote and revised the manuscript. WCC and $\mathrm{CCH}$ designed the study. CCH coordinated the study. All authors read and approved the final manuscript.

\section{Competing interests}

The authors declare no competing interests.

\section{Consent for publication}

Not applicable.

Ethics approval and consent to participate Not applicable.

\section{Publisher's Note}

Springer Nature remains neutral with regard to jurisdictional claims in published maps and institutional affiliations.

\section{Author details}

${ }^{1}$ Department of Life Sciences, National Chung Hsing University, Taichung, Taiwan. ${ }^{2}$ Center of Cold Chain Logistics Certification, College of Management, National Kaohsiung First University of Science and Technology, Kaohsiung, Taiwan. ${ }^{3}$ Institute of Genomics and Bioinformatics, National Chung Hsing University, Taichung 402, Taiwan. ${ }^{4}$ Graduate School of Science, Technology and Innovation, Kobe University, Kobe, Japan.

Received: 27 October 2016 Accepted: 22 March 2017 Published online: 11 April 2017

\section{References}

1. Ezeji TC, Qureshi N, Blaschek HP. Bioproduction of butanol from biomass: from genes to bioreactors. Curr Opin Biotechnol. 2007;18(3):220-7.

2. Green EM. Fermentative production of butanol-the industrial perspective. Curr Opin Biotechnol. 2011;22(3):337-43.

3. Procentese A, Raganati F, Olivieri G, Russo ME, De La Feld M, Marzocchella A. Renewable feedstocks for biobutanol production by fermentation. N Biotechnol. 2016. doi: 10.1016/j.nbt.2016.10.010.

4. Harvey BG, Meylemans HA. The role of butanol in the development of sustainable fuel technologies. J Chem Technol Biotechnol. 2011; 86(1):2-9.

5. Atsumi S, Cann AF, Connor MR, Shen CR, Smith KM, Brynildsen MP, et al. Metabolic engineering of Escherichia coli for 1-butanol production. Metab Eng. 2008;10(6):305-11.

6. Inui M, Suda M, Kimura S, Yasuda K, Suzuki H, Toda H, et al. Expression of Clostridium acetobutylicum butanol synthetic genes in Escherichia coli. Appl Microbiol Biotechnol. 2008;77(6):1305-16.

7. Dellomonaco C, Clomburg JM, Miller EN, Gonzalez R. Engineered reversal of the beta-oxidation cycle for the synthesis of fuels and chemicals. Nature 2011:476(7360):355-9.

8. Shen CR, Lan El, Dekishima Y, Baez A, Cho KM, Liao JC. Driving forces enable high-titer anaerobic 1-butanol synthesis in Escherichia coli. Appl Environ Microbiol. 2011;77(9):2905-15

9. Ye $\mathrm{O}$, Bao J, Zhong J-J. Bioreactor Engineering Research and Industrial Applications I: Cell Factories. 1st ed. Springer: Berlin; 2016. https://link. springer.com/book/10.1007\%2F978-3-662-49161-4.

10. Bowles LK, Ellefson WL. Effects of butanol on Clostridium acetobutylicum. Appl Environ Microbiol. 1985;50(5):1165-70.

11. Knoshaug EP, Zhang M. Butanol tolerance in a selection of microorganisms. Appl Biochem Biotechnol. 2009;153(1-3):13-20.

12. Mao S, Luo Y, Zhang T, Li J, Bao G, Zhu Y, et al. Proteome reference map and comparative proteomic analysis between a wild type Clostridium acetobutylicum DSM 1731 and its mutant with enhanced butanol tolerance and butanol yield. J Proteome Res. 2010;9(6):3046-61.

13. Liu XB, Gu QY, Yu XB. Repetitive domestication to enhance butanol tolerance and production in Clostridium acetobutylicum through artificial simulation of bio-evolution. Bioresour Technol. 2013;130:638-43.

14. Tomas CA, Beamish J, Papoutsakis ET. Transcriptional analysis of butanol stress and tolerance in Clostridium acetobutylicum. J Bacteriol. 2004;186(7):2006-18.

15. Gonzalez R, Tao H, Purvis JE, York SW, Shanmugam KT, Ingram LO. Gene array-based identification of changes that contribute to ethanol tolerance in ethanologenic Escherichia coli: comparison of KO11 (parent) to LY01 (resistant mutant). Biotechnol Prog. 2003;19(2):612-23.

16. Brynildsen MP, Liao JC. An integrated network approach identifies the isobutanol response network of Escherichia coli. Mol Syst Biol. 2009;5:277.

17. Rutherford BJ, Dahl RH, Price RE, Szmidt HL, Benke PI, Mukhopadhyay A, et al. Functional genomic study of exogenous n-butanol stress in Escherichia coli. Appl Environ Microbiol. 2010;76(6):1935-45

18. Sigler K, Chaloupka J, Brozmanova J, Stadler N, Hofer M. Oxidative stress in microorganisms-l. Microbial vs. higher cells-damage and defenses in relation to cell aging and death. Folia Microbiol (Praha). 1999:44(6):587-624

19. Perrone GG, Tan SX, Dawes IW. Reactive oxygen species and yeast apoptosis. Biochim Biophys Acta. 2008;1783(7):1354-68. 
20. Jones DP. Radical-free biology of oxidative stress. Am J Physiol Cell Physiol 2008;295(4):C849-68.

21. Fridovich I. Superoxide radical and superoxide dismutases. Annu Rev Biochem. 1995:64:97-112.

22. Imlay JA. Pathways of oxidative damage. Annu Rev Microbiol. 2003;57:395-418.

23. Coyle P, Philcox JC, Carey LC, Rofe AM. Metallothionein: the multipurpose protein. Cell Mol Life Sci. 2002;59(4):627-47.

24. Vallee BL. The function of metallothionein. Neurochem Int. 1995:27(1):23-33.

25. Park JD, Liu Y, Klaassen CD. Protective effect of metallothionein against the toxicity of cadmium and other metals(1). Toxicology. 2001;163(2-3):93-100.

26. Sato $M$, Kondoh $M$. Recent studies on metallothionein: protection against toxicity of heavy metals and oxygen free radicals. Tohoku J Exp Med. 2002;196(1):9-22.

27. Lin $\mathrm{KH}$, Chien MF, Hsieh $J \mathrm{~L}$, Huang CC. Mercury resistance and accumulation in Escherichia coli with cell surface expression of fish metallothionein. Appl Microbiol Biotechnol. 2010;87(2):561-69.

28. Chin WC, Lin KH, Chang JJ, Huang CC. Improvement of n-butanol tolerance in Escherichia coli by membrane-targeted tilapia metallothionein. Biotechnol Biofuels. 2013;6(1):130

29. Tsuge K, Matsui K, Itaya M. One step assembly of multiple DNA fragments with a designed order and orientation in Bacillus subtilis plasmid. Nucleic Acids Res. 2003;31(21):e133.

30. Zhu L, Dong H, Zhang Y, Li Y. Engineering the robustness of Clostridium acetobutylicum by introducing glutathione biosynthetic capability. Metab Eng. 2011;13(4):426-34.

31. Boyarskiy S, Davis Lopez S, Kong N, Tullman-Ercek D. Transcriptional feedback regulation of efflux protein expression for increased tolerance to and production of n-butanol. Metab Eng. 2016;33:130-7.

32. Kempf B, Bremer E. Uptake and synthesis of compatible solutes as microbial stress responses to high-osmolality environments. Arch Microbiol. 1998;170(5):319-30.

33. Zhang $H$, Chong $H$, Ching $C B$, Song $H$, Jiang R. Engineering global transcription factor cyclic AMP receptor protein of Escherichia coli for improved 1-butanol tolerance. Appl Microbiol Biotechnol. 2012;94(4): 1107-17.

34. Zingaro KA, Terry PE. GroESL overexpression imparts Escherichia col tolerance to i-, n-, and 2-butanol, 1,2,4-butanetriol and ethanol with complex and unpredictable patterns. Metab Eng. 2013;15:196-205.

35. Yuan Y, Bi C, Nicolaou SA, Zingaro KA, Ralston M, Papoutsakis ET. Overexpression of the Lactobacillus plantarum peptidoglycan biosynthesis murA2 gene increases the tolerance of Escherichia coli to alcohols and enhances ethanol production. Appl Microbiol Biotechnol. 2014;98(19):8399-411.

36. Zingaro KA, Nicolaou SA, Yuan Y, Papoutsakis ET. Exploring the heterologous genomic space for building, stepwise, complex, multicomponent tolerance to toxic chemicals. ACS Synth Biol. 2014;3(7):476-86.

37. Watanabe R, Doukyu N. Improvement of organic solvent tolerance by disruption of the lon gene in Escherichia coli. J Biosci Bioeng. 2014;118(2): 139-44

38. le Bui M, Lee JY, Geraldi A, Rahman Z, Lee JH, Kim SC. Improved n-butanol tolerance in Escherichia coli by controlling membrane related functions. J Biotechnol. 2015;204:33-44.

39. Si HM, Zhang F, Wu AN, Han RZ, Xu GC, Ni Y. DNA microarray of global transcription factor mutant reveals membrane-related proteins involved in n-butanol tolerance in Escherichia coli. Biotechnol Biofuels. 2016;9:114.

40. Mialon L, Vanderhenst R, Pemba AG, Miller SA. Polyalkylenehydroxybenzoates (PAHBs): biorenewable aromatic/ aliphatic polyesters from lignin. Macromol Rapid Commun. 2011; 32(17):1386-92

41. Polen T, Spelberg M, Bott M. Toward biotechnological production of adipic acid and precursors from biorenewables. J Biotechnol. 2013;167(2):75-84.

42. Steen EJ, Kang Y, Bokinsky G, Hu Z, Schirmer A, McClure A, et al. Microbial production of fatty-acid-derived fuels and chemicals from plant biomass. Nature. 2010;463(7280):559-62.

43. Lennen RM, Kruziki MA, Kumar K, Zinkel RA, Burnum KE, Lipton MS, et al. Membrane stresses induced by overproduction of free fatty acids in Escherichia coli. Appl Environ Microbiol. 2011;77(22):8114-28.

44. Jarboe LR, Royce LA, Liu P. Understanding biocatalyst inhibition by carboxylic acids. Front Microbiol. 2013;4:272.

45. Lennen RM, Pfleger BF. Modulating membrane composition alters free fatty acid tolerance in Escherichia coli. PLoS One. 2013;8(1):e54031.
46. Royce LA, Yoon JM, Chen Y, Rickenbach E, Shanks JV, Jarboe LR. Evolution for exogenous octanoic acid tolerance improves carboxylic acid production and membrane integrity. Metab Eng. 2015;29:180-8.

47. Tan Z, Yoon JM, Nielsen DR, Shanks JV, Jarboe LR. Membrane engineering via trans unsaturated fatty acids production improves Escherichia coli robustness and production of biorenewables. Metab Eng. 2016;35:105-13.

48. Ingram L. Microbial tolerance to alcohols: role of the cell membrane. Trends Biotechnol. 1986;4(2):40-4

49. Aono R, Nakajima H. Organic solvent tolerance in Escherichia coli. Tanpakushitsu Kakusan Koso. 1997;42(15):2532-41.

50. Ingram LO, Buttke TM. Effects of alcohols on micro-organisms. Adv Microb Physiol. 1984;25:253-300.

51. Kabelitz N, Santos PM, Heipieper HJ. Effect of aliphatic alcohols on growth and degree of saturation of membrane lipids in Acinetobacter calcoaceticus. FEMS Microbiol Lett. 2003;220(2):223-7.

52. Trautwein K, Kuhner S, Wohlbrand L, Halder T, Kuchta K, Steinbuchel A, et al Solvent stress response of the denitrifying bacterium "Aromatoleum aromaticum" strain EbN1. Appl Environ Microbiol. 2008;74(8):2267-74.

53. Minty JJ, Lesnefsky AA, Lin F, Chen Y, Zaroff TA, Veloso AB, et al. Evolution combined with genomic study elucidates genetic bases of isobutanol tolerance in Escherichia coli. Microb Cell Fact. 2011;10:18.

54. Ingram LO. Ethanol tolerance in bacteria. Crit Rev Biotechnol. 1990;9(4):305-19.

55. Goodarzi H, Bennett BD, Amini S, Reaves ML, Hottes AK, Rabinowitz JD, et al. Regulatory and metabolic rewiring during laboratory evolution of ethanol tolerance in E. coli. Mol Syst Biol. 2010;6:378.

56. Woodruff LB, Pandhal J, Ow SY, Karimpour-Fard A, Weiss SJ, Wright PC, et al. Genome-scale identification and characterization of ethanol tolerance genes in Escherichia coli. Metab Eng. 2013;15:124-33.

57. Asako H, Nakajima H, Kobayashi K, Kobayashi M, Aono R. Organic solvent tolerance and antibiotic resistance increased by overexpression of marA in Escherichia coli. Appl Environ Microbiol. 1997;63(4):1428-33.

58. Dien BS, Cotta MA, Jeffries TW. Bacteria engineered for fuel ethanol production: current status. Appl Microbiol Biotechnol. 2003;63(3):258-66.

59. Luo LH, Seo PS, Seo JW, Heo SY, Kim DH, Kim CH. Improved ethanol tolerance in Escherichia coli by changing the cellular fatty acids composition through genetic manipulation. Biotechnol Lett. 2009;31(12):1867-71.

60. Jarboe $L R$, Liu P, Royce LA. Engineering inhibitor tolerance for the production of biorenewable fuels and chemicals. Curr Opin Chem Eng. 2011;1 (1):38-42.

61. Ramskold D, Wang ET, Burge CB, Sandberg R. An abundance of ubiquitously expressed genes revealed by tissue transcriptome sequence data. PLoS Comput Biol. 2009;5(12):e1000598.

62. Ingledew WJ, Poole RK. The respiratory chains of Escherichia coli. Microbiol Rev. 1984;48(3):222-71.

63. Georgellis D, Kwon O, Lin EC. Quinones as the redox signal for the arc twocomponent system of bacteria. Science. 2001;292(5525):2314-6.

64. Malpica R, Franco B, Rodriguez C, Kwon O, Georgellis D. Identification of a quinone-sensitive redox switch in the ArcB sensor kinase. Proc Natl Acad Sci U S A. 2004;101(36):13318-23.

65. Malpica R, Sandoval GR, Rodriguez C, Franco B, Georgellis D. Signaling by the arc two-component system provides a link between the redox state of the quinone pool and gene expression. Antioxid Redox Signal. 2006;8(5-6):781-95.

66. Saini M, Li SY, Wang ZW, Chiang CJ, Chao YP. Systematic engineering of the central metabolism in Escherichia coli for effective production of n-butanol. Biotechnol Biofuels. 2016;9:69.

67. Du Toit PJ, Kotze JP. The isolation and characterization of sorbitol-6phosphate dehydrogenase from Clostridium pasteurianum. Biochim Biophys Acta. 1970;206(3):333-42.

68. Hacking AJ, Lin EC. Disruption of the fucose pathway as a consequence of genetic adaptation to propanediol as a carbon source in Escherichia coli. J Bacteriol. 1976;126(3):1166-72.

69. White D. The physiology and biochemistry of prokaryotes. 3rd ed. New York: Oxford University Press; 2007

70. Sundara Sekar B, Seol E, Mohan Raj S, Park S. Co-production of hydrogen and ethanol by pfkA-deficient Escherichia coli with activated pentosephosphate pathway: reduction of pyruvate accumulation. Biotechnol Biofuels. 2016:9:95.

71. Sauer U, Canonaco F, Heri S, Perrenoud A, Fischer E. The soluble and membranebound transhydrogenases UdhA and PntAB have divergent functions in NADPH metabolism of Escherichia coli. J Biol Chem. 2004;279(8):6613-9.

72. Bolger AM, Lohse M, Usadel B. Trimmomatic: a flexible trimmer for Illumina sequence data. Bioinformatics. 2014;30(15):2114-20. 
73. Trapnell C, Roberts A, Goff L, Pertea G, Kim D, Kelley DR, et al. Differential gene and transcript expression analysis of RNA-seq experiments with TopHat and Cufflinks. Nat Protoc. 2012;7(3):562-78.

74. NIH DAVID Bioinformatics Resources 6.7. Available online: http://david.abcc. ncifcrf.gov/(accessed on 28 Dec 2014).

75. Nishizaki T, Tsuge K, Itaya M, Doi N, Yanagawa H. Metabolic engineering of carotenoid biosynthesis in Escherichia coli by ordered gene assembly in Bacillus subtilis. Appl Environ Microbiol. 2007;73(4):1355-61.

Submit your next manuscript to BioMed Central and we will help you at every step:

- We accept pre-submission inquiries

- Our selector tool helps you to find the most relevant journal

- We provide round the clock customer support

- Convenient online submission

- Thorough peer review

- Inclusion in PubMed and all major indexing services

- Maximum visibility for your research

Submit your manuscript at www.biomedcentral.com/submit 